AJChE 2013, Vol. 13, No. 1, 33-42

\title{
The Initial Dioxigenase Gene Squences Analysis of Marine Bacteria Strain M128
}

Muhamad Sahlan ${ }^{1}$

Hanif Yuliani ${ }^{1,2}$

Heri Hermansyah ${ }^{1}$

Anondho Wijanarko *1

1 Department of Chemical Engineering, Faculty of Engineering, Universitas Indonesia, Kampus UI - Depok, Depok, 16424, Indonesia

${ }^{2}$ Center for the Industrial Processed of Technology, the Agency for the Assessment and Application of Technology (BPPT), Jakarta, 10340, Indonesia

*e-mail : anondho@eng.ui.ac.id

Biodegradation of polyaromatic hydrocarbons (PAHs) are catalyzed by multicomponent enzymes from microbe. The initial dioxygenase was used as a key enzyme for attacking the aromatic ring structure of PAHs, furthermore its initial dioxygenase gene was used to select PAHs degrading bacteria. Marine bacteria M128 strain could grow on medium contained PAHs. Detection of its cellular initial deoxygenase gene was done by nahAc gene amplification. The nahAc gene commonly used as biomarkers of PAH degradation, and as a result, nahAc gene sequence analysis of marine bacteria M128 strain was similar to naphthalene dioxygenase of Pseudomonas genera with $99 \%$ homology.

Keywords: Biodegradation, Dioxygenase, Gene sequence, Analysis, PAHs

\section{INTRODUCTION}

Consumption of petroleum product as an energy source has increased together with increasing of community live style as an impact of rapid consume growth. Petroleum product exploration activities caused waste pollution to environment, thus creating a seriously imbalance in the biotic and a-biotic regimes of the ecosystem (Okoh and Trejo-Hernandez, 2006). Oil and gas exploitation produced significant amount of petroleum sludge. Nowadays domestical petroleum production produced around 2 Kton oil sludge per day (Helmy et al, 2010).
Characterization of petroleum sludge from Pertamina Refinery Unit V, Balikpapan, Indonesia show that around $13.24 \%$ oil sludge contains PAHs. PAHs are one of the most widespread organic pollutants and potentially hazard to human health (Arun et $a l$, 2011).

Natural characteristic of PAHs are carcinogenic, mutagenic, and teratogenic which expose to the environment, human health, and aquatic ecosystems, and become severe hazard effect, therefore $\mathrm{PAHs}$ remediation for reducing its hazard effect become one of the government concern. One of the most effective and efficient way to remove this contamination 
is bioremediation by using selected microorganism locally isolated from Indonesian territorial that have high capability to degrade PAHs.

Bioremediation is commonly used for recovery PAHs contaminated environment. The usage of potential fitted microbia will increase the efficiency of environment recovery processing. Guo et al (2010) reported the high ability of microbia to degrade PAHs influenced by the precense of dioxygenase gene. Sho et al (2004) and Zhou et al (2006) also reported that the initial dioxgenase was became biomarker for PAHs degradation microbia.

Genetic sequence analysis of PAHs degradation ability from domestically bacteria that was isolated from Indonesian marine was done and also potential to increase biological remediation of oil sludge. Detection of the dioxigenase gene (nahAc gene) from M128 strains was done in order to revealed the potential ability of the strain for PAHs degradation and as result, genetical sequence of this dioxogenase gene was also reported.

\section{MATERIALS AND METHODS}

\section{Microorganism}

Bacterial strain M128 is a collection strain from Research Center for Biotechnology, Indonesian Institute of Science and isolated from Indonesian marine which then was selected after cultivation in agar plate contained $20 \mathrm{mg} / \mathrm{l}$ pyrene and phenanthrene.

\section{Culture media}

Genomic DNA of M128 strain was extracted by using Miobio-laboratories kit after growth on LB medium for 18 hours (Prágai and Harwoord, 2000).

\section{Detection of PAH-degrading dioxygenase M128 strain (Zhou et al, 2006)}

The presence of the initial dioxygenase gene was detected base on PCR amplification. The primers for nahAc gene amplification were listed in Table 1.

Table 1. $P C R$ Primer for the detection nahAc gene (Zhou et al, 2006)

\begin{tabular}{ll}
\hline \multicolumn{1}{c}{ Primer } & \multicolumn{1}{c}{ Sequence } \\
\hline nahAc- & Forward primer: Nah-for \\
first PCR & TGCMVNTAYCAYGGYTGG \\
\cline { 2 - 2 } & Reverse primer: Nah-rev 1 \\
& CCCGGTARWANCCDCKRTA \\
\hline nahAc- & Forward primer : Nah-for \\
nested PCR & TGCMVNTAYCAYGGYTGG \\
\cline { 2 - 2 } & Reverse primer: Nah-rev 2 \\
& CRGGTGYCTTCCAGTTG \\
\hline
\end{tabular}

PCR solution contain $5 \mu \mathrm{L}$ buffer, $4 \mu \mathrm{L}$ dNTPs, $1 \mu \mathrm{L}$ forward primer, $1 \mu \mathrm{L}$ reverse primer, $1 \mu \mathrm{L}$ DNA template, $0.25 \mu \mathrm{L}$ Ex Taq DNA polymerase and sterile distilled water to a final volume $50 \mu \mathrm{L}$. The PCR cycle conditions were listed in Table 2.

PCR amplification of nahAc gene is performed using genomic DNA of M128 strain as template. The first round PCR products is used as template for second $P C R$. The first and second round PCR products is analysed by electrophoresis in 2 $\%$ agarose gel.

\section{Ligation and transformation of nahAc} gene (Prágai et al, 1997)

The second round PCR product is separated by electrophoresis in a $2 \%(\mathrm{w} / \mathrm{v})$ 
Table 2. PCR condition for nahAc gene amplification (Zhou et al, 2006)

\begin{tabular}{|c|c|}
\hline \multirow[b]{2}{*}{ First round $P C R$} & - Initiation $94^{\circ} \mathrm{C}$ for $3 \mathrm{~min}$ \\
\hline & $\begin{array}{l}\text { - Amplification } 30 \text { cycles }\left(94{ }^{\circ} \mathrm{C} 45 \mathrm{~s}, 55^{\circ} \mathrm{C} 45 \mathrm{~s} \text {, }\right. \\
\text { and } 72{ }^{\circ} \mathrm{C} 45 \text { second) } \\
\text { - Final extension : } 72{ }^{\circ} \mathrm{C} \text { for } 5 \mathrm{~min}\end{array}$ \\
\hline & - Initiation $94^{\circ} \mathrm{C}$ for $3 \mathrm{~min}$ \\
\hline $\begin{array}{l}\text { Second round PCR } \\
\text { (nested PCR) }\end{array}$ & $\begin{array}{l}\text { - Amplification } 40 \text { cycles }\left(94{ }^{\circ} \mathrm{C} 45 \mathrm{~s}, 55{ }^{\circ} \mathrm{C} 45 \mathrm{~s} \text {, }\right. \\
\left.\text { and } 72{ }^{\circ} \mathrm{C} 45 \text { second }\right) \\
\text { - Final extension : } 72{ }^{\circ} \mathrm{C} \text { for } 5 \mathrm{~min}\end{array}$ \\
\hline
\end{tabular}

agarose gel and ethidium bromide staining. The target bands were cut off on UV Transilluminator then recovered and purified by gene clean using glass-milk. The purified DNA fragment was linked to pMD20 vector by using ligation mixture at $16{ }^{\circ} \mathrm{C}$ for 15 $\min$, and then this recombinant vector is transformed into competence cells Escherichia coli $\mathrm{DH} 5 \alpha$. The blue-white selection and PCR screening method are carried out to identify positive recombinant clone.

\section{Plasmid Extraction}

Plasmid extraction is done after the competent cell Escherichia coli $\mathrm{DH} 5 \alpha$ growing on LB ampicillin medium for 18 hours. This extraction is done by using
alkali-SDS method (Prágai and Harwoord, 2000; Prágai et al, 1997).

\section{Sequence analysis of nahAc gene strain M128 (Herrick et al, 1993)}

Polymerase chain reaction (PCR) is performed for nahAc gene strains M128 sequence analysis. Composition of PCR solution for nahAc gene sequence analysis is listed in Table 3.

The PCR condition of nahAc gene sequence analysis consist of initial denaturation $96^{\circ} \mathrm{C}$ for 5 min, than 25 cycles $\left(96{ }^{\circ} \mathrm{C}\right.$ for $1 \mathrm{~min}, 50{ }^{\circ} \mathrm{C}$ for 30 seconds, $60^{\circ} \mathrm{C}$ for $1 \mathrm{~min}$ ). PCR product is purified using BigDye ${ }^{\circledR} X$ Terminator ${ }^{\text {TM}}$ Purification Kit. Purified PCR product is sequenced using BigDye ${ }^{\circledR}$ TerminatorV3.1 Kit Applied

Table 3. PCR solution component for sequencing nahAc gene

\begin{tabular}{|c|c|}
\hline \multirow{5}{*}{$\begin{array}{l}\text { Reverse } \\
\text { sequence }\end{array}$} & $100-250$ ng purified plasmid (ds DNA template) \\
\hline & $2 \mu \mathrm{l}$ Reverse Primer (M13-Rv primer) \\
\hline & $1 \mu \mathrm{l}$ BigDyeV3.1 Primer \\
\hline & $2 \mu l$ sequence buffer \\
\hline & $\mathrm{dH}_{2} \mathrm{O}$ up to $10 \mu \mathrm{l}$ \\
\hline \multirow{5}{*}{$\begin{array}{l}\text { forward } \\
\text { sequence }\end{array}$} & $100-250$ ng purified plasmid (ds DNA template) \\
\hline & $2 \mu \mathrm{l}$ forward primer (M13M4 Primer) \\
\hline & $1 \mu \mathrm{l}$ BigDyeV3.1 Primer \\
\hline & $2 \mu \mathrm{l}$ sequence buffer \\
\hline & $\mathrm{dH}_{2} \mathrm{O}$ up to $10 \mu \mathrm{l}$ \\
\hline
\end{tabular}


Biosystems. Furthermore, this genetical sequence is submitted to GenBank data base to search for similarity with other dioxygenase gene sequences by using Blast alignment tool on The National Center of Biotechnology Information (NCBI) website.

\section{RESULTS}

\section{Detection of nahAc gene M128 strain}

For investigation of dioxygenase gene that was encoded initial polyaromatics hydrocarbons dioxygenase, M128 strain was analyzed by PCR amplification to detect the presence of nahAc gene. The nahAc gene encoded naphthalene dioxygenase was commonly used as biomarkers of PAH degradation (Zhou et al, 2006).

PCR amplification of nahAc gene used genomic DNA of M128 strains as template. Product of first and second round of PCR product were analyzed by electrophoresis in $2 \%$ agarose gel. Figure 1 shows first round PCR product for about $900 \mathrm{bp}$, and Figure 2 shows second round PCR product that have molecular weight for about 400 bp.

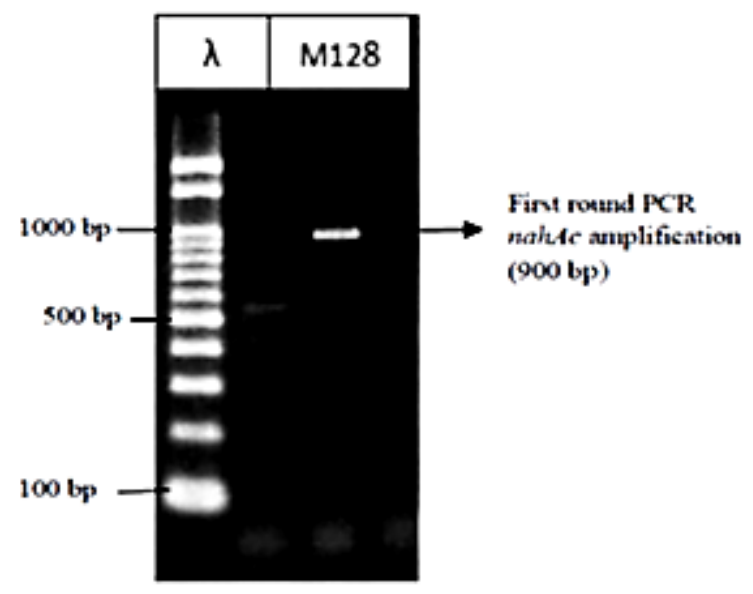

Fig. 1: First round PCR product of amplified nahAc gene fragmen separated by $2 \%$ agarose gel

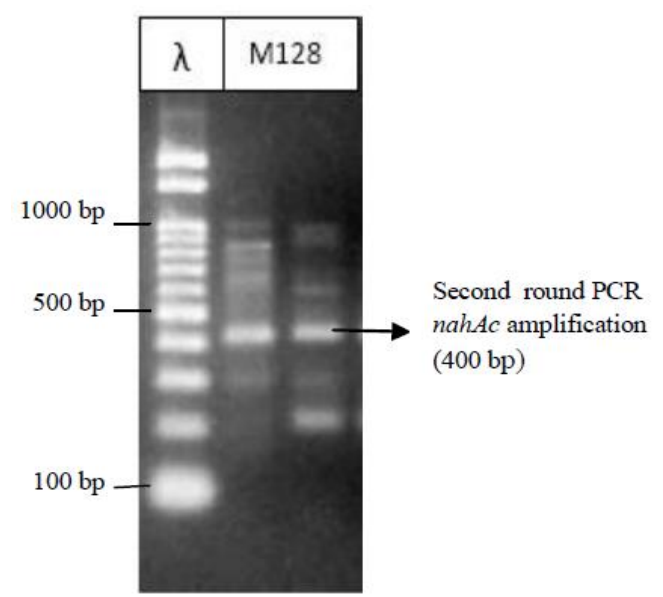

Fig. 2: Second round PCR product of amplified nahAc gene fragment separated by $2 \%$ agarose gel. 


\section{Ligation and Transformation of nahAc gene}

Positive recombinant clone were identified by blue-white selection and PCR screening method. Figure 3 shows PCR screening result of $E$. coli $\mathrm{DH} 5 \alpha$ that was inserted by nahAc gene from first round PCR product strain M128.

\section{Plasmid Extraction}

Figure 4 shows bands of plasmid after cutting by both $\mathrm{BamHI}$ and $\mathrm{Xbal}$ restriction enzyme. This plasmid have been cut completely by this restriction enzyme, therefore there are 2 bands, for about 900 bp comes from nahAc fragment gene and \pm 2800 bp from pmD20 vector band.

\section{Sequence Analysis of dioxygenase gene M128 strain}

Sequence analysis of nahAc gene M128 strain by using Blast alignment tool revealed that nahAc gene M128 strain has similarity with nah gene from Pseudomonas genera with $99 \%$ homology. Table 4 show comparison result of similarity of nahAc

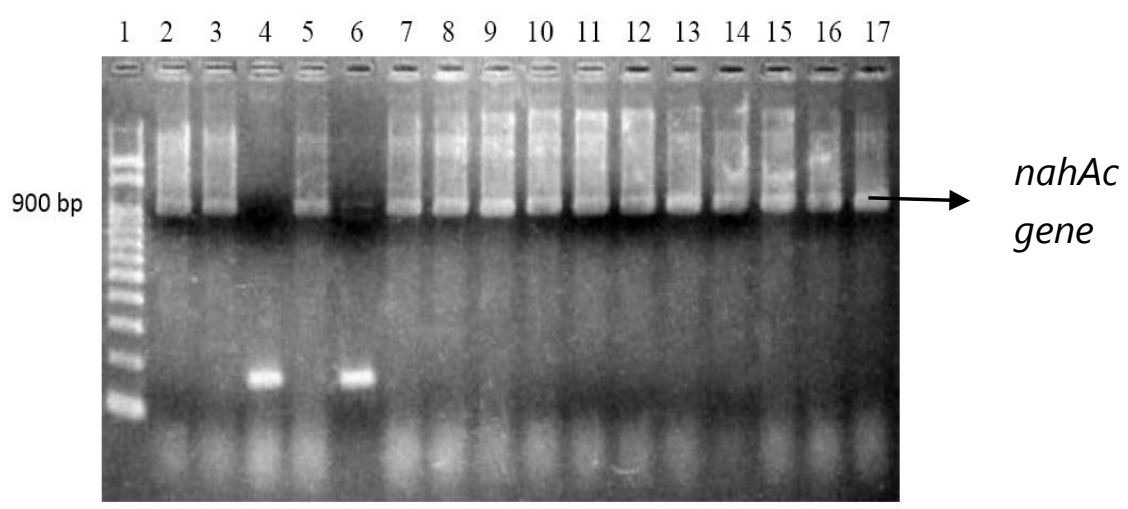

Fig. 3: Selection of competence cells $E$. coli $\mathrm{DH} 5 \alpha$ transformed with plasmid contain nahAc gene strain M128. (1.Standard, 2. M128-1, 3. M128-2, 4. M128-3, 5. M128-4, 6. M128-5, 7. M128-6, 8. M128-7, 9. M128-8, 10. M128-9, 11. M128-10, 12. M128-11, 13. M128 12, 14. M128-13, 15. M128-14, 16. M128-15, 17. M128-16)

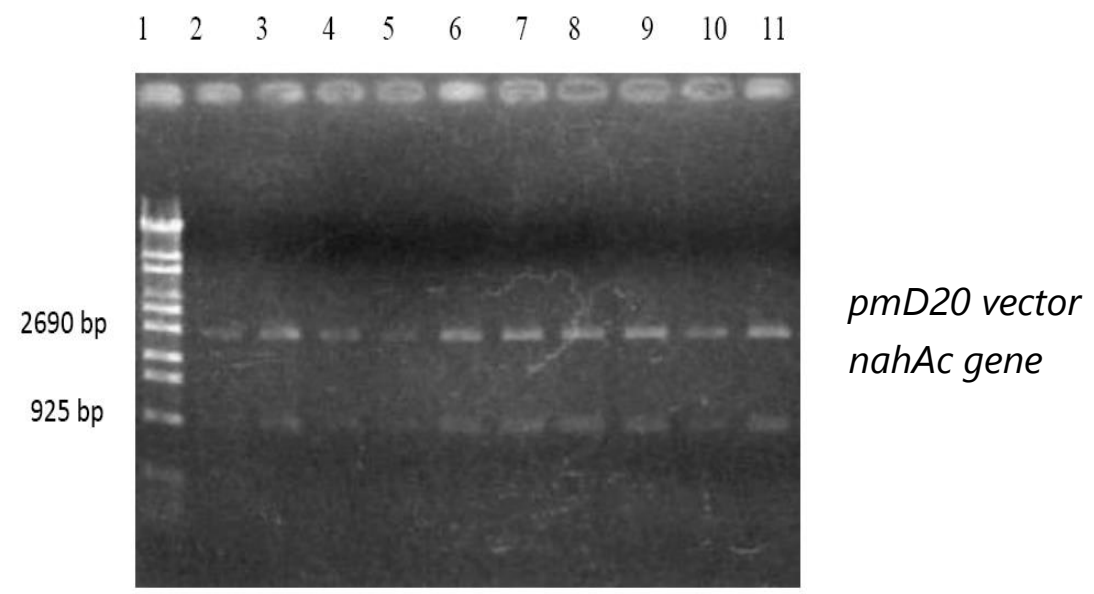

Fig. 4: Plasmid contains nahAc gene was cut by BamH-I and $\mathrm{Xbal}$ restriction enzymes (1.Standard, 2. M128-7, 3. M128-8, 4. M128-9, 5. M128-10, 6. M128-11, 7. M128-12, 8. $\mathrm{M} 128-13,9 . \mathrm{M} 128-14$, 10. $\mathrm{M} 128-15,11 . \mathrm{M} 128-16)$ 
Table 4. Compare result of the protein similarity of nahAc gene M128 strain with other bacterial gene cluster

\begin{tabular}{|c|c|c|}
\hline $\begin{array}{l}\text { Accession } \\
\text { No. }\end{array}$ & Microbia & Similarity \\
\hline $\begin{array}{l}\text { dbj|D84146.1| } \\
\text { PSEORF1 }\end{array}$ & $\begin{array}{l}\text { Pseudomonas aeruginosa PAH genes for } 12 \text { ORFs } \\
\text { (components of naphthalene dioxygenase, } \\
\text { dehydrogenase, hydratase-aldolase, isomerase), } \\
\text { Length }=12808\end{array}$ & $\begin{array}{l}\text { Score }=1696 \text { bits }(918), \\
\text { Expect }=0.0 \\
\text { Identities }=944 / 957(99 \%), \\
\text { Gaps }=0 / 957(0 \%)\end{array}$ \\
\hline $\begin{array}{l}\text { gb|HM36864 } \\
9.1\end{array}$ & $\begin{array}{l}\text { Pseudomonas sp. N1 naphthalene dioxygenase gene } \\
\text { cluster, complete sequence, Length = } 3461\end{array}$ & $\begin{array}{l}\text { Score }=1694 \text { bits }(917), \\
\text { Expect }=0.0 \\
\text { Identities }=943 / 956(99 \%), \\
\text { Gaps }=0 / 956(0 \%)\end{array}$ \\
\hline $\begin{array}{l}\text { gb|AF039533. } \\
\text { 1|AF039533 }\end{array}$ & $\begin{array}{l}\text { Pseudomonas stutzeri naphthalene degradation } \\
\text { upper-pathway gene cluster (nahAa, nahAb, nahAc, } \\
\text { nahAd, nahB, nahF, nahC, nahE, and nahD) and } \\
\text { transposon-like protein (tnpA1) gene, complete cds, } \\
\text { Length = } 11514\end{array}$ & $\begin{array}{l}\text { Score }=1677 \text { bits }(908), \\
\text { Expect }=0.0 \\
\text { Identities }=941 / 957(98 \%), \\
\text { Gaps }=2 / 957(0 \%)\end{array}$ \\
\hline
\end{tabular}

gene M128 strain with other bacterial gene which was downloaded from GenBank database.

Phylogenetic analysis of M128 strain's nahAc gene found that this nahAc gene homolog with Pseudomonas genera's nahAc gene which was known have ability to degrade PAHs (Grimm and Harwood (1997), Figure 5).

\section{DISCUSSION}

PAHs biodegradation process was initiated by dioxygenase of aromatic rings. Kim et al (2007) was reported pyrene biodegration by Mycobacterium vanbaalenii strain was initiated by the dioxigenase of pyrene compounds formed cis-4,5- pyrene dihydrodiol and 4,5dihydroxy pyrene. Iwabuchi and Harayama (1997) and Stingley et al (2004) reported that phenanthrene biodegradation was also initiated by dioxygenase of phenanthrene compounds for producing phenanthrene 3,4-dihydrodiol. Soe et al (2009) revealed that bacterial PAHs biodegradation was also initiated by dioxgenase reaction. Therefore the dioxygenase gene became important prevalent for microbial ability in PAHs degradation.

Zhou et al (2006) found that presence of dioxygenase gene for selecting the potential PAHs degradation isolates. This selection was done by amplification of nidA, phdA, narAa, pdoA, nahAc, nagAc, phnAc, dan arc gene. Furthermore Guo et al (2010) also selected potential bacteria by using nahAc, nidA, and $p d o B$ gene amplification. Guo's result concluded that high biodegradation of phenanthrene, fluoranthene, and pyrene were done by bacterias that have dioxygenase gene. Therefore M128 strain that has dioxygenase gene (nahAc gene) was also have high potential ability for PAHs 


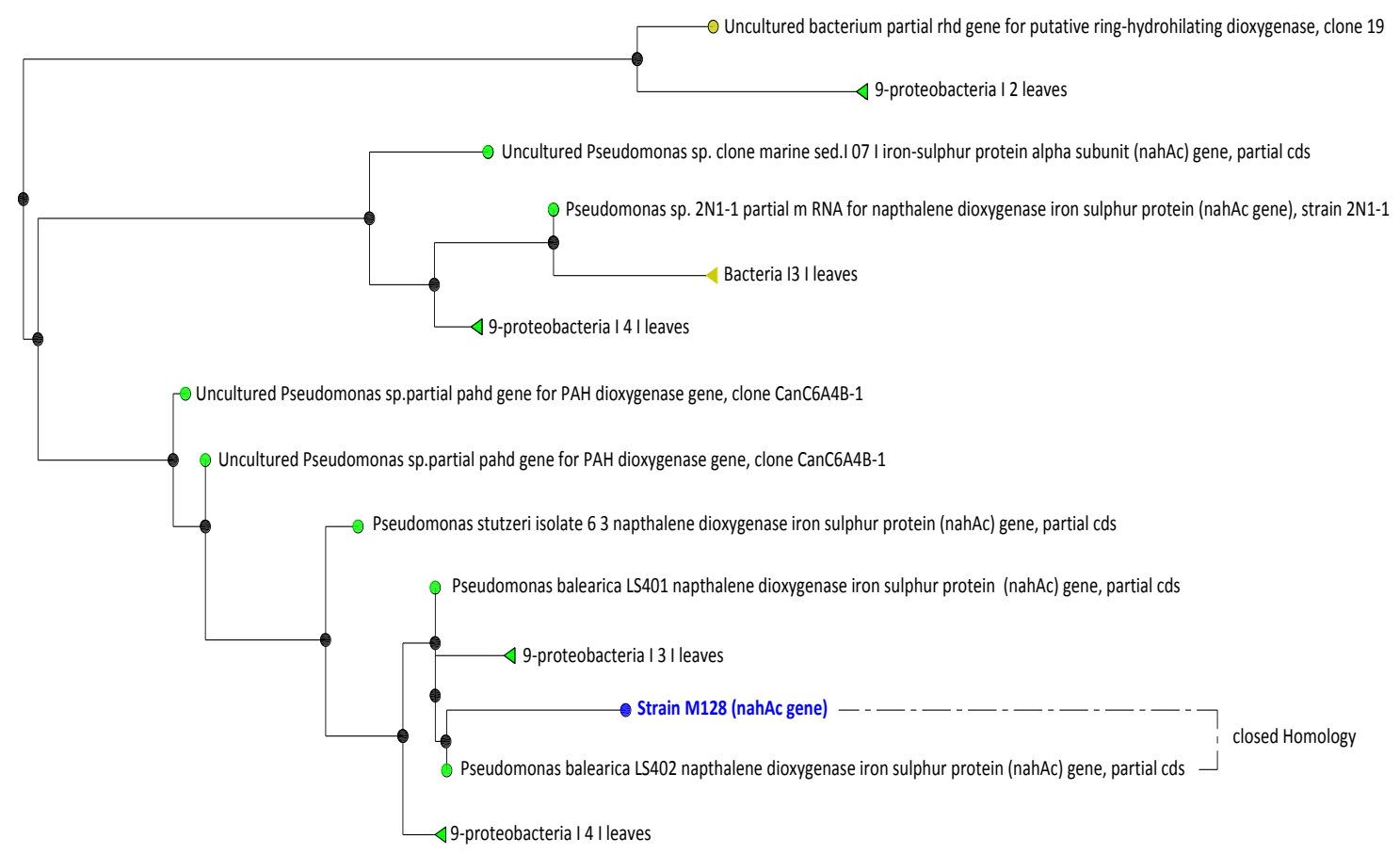

Fig. 5: Phylogenetics analysis of nahAc gene M128 strain.

degradation.

Sequence analysis of dioxygenase gene from M128 strain revealed that dioxigenase gene from this strain was similar with naphthalene dioxygenase (nahAc) gene from Pseudomonas genera with $99 \%$ homology. Grimm and Harwood (1997) reported biodegradation of PAHs naphtalene by nah gene from Pseudomonas sp. and revealed that napthalene was degraded and formed salicilate, catechol and then continue by meta cleavage pathway to formed acetylCoA as shown in Figure 6. As a result, the nah gene is specify for napthalene degradation to be pyruvate and acetylcoenzyme-A (CoA) via meta cleavage. From dioxygenase gene of $M 128$ strain sequence analysis result, it was known that this strain could completely degrade PAHs to form pyruvate and acetyl-coenzyme A (CoA) via meta cleavage, and continued to tricarboxylic acid (TCA) cycle for completely degradation.

For next step research activity, based on PAH degradation pathway which was concluded in this experimental result, it is necessary to make more in - depth study on reaction kinetic of PAH bioremediation using this Bacillus strain as a complementary for large - scale oil sludge waste treatment purpose.

\section{CONCLUSION}

Domestical marine bacteria strain M128 which could grow on medium contained $\mathrm{PAHs}$, has nahAc gene which is responsible for initial dioxygenase of PAHs degradation. This nahAc gene has similarity 


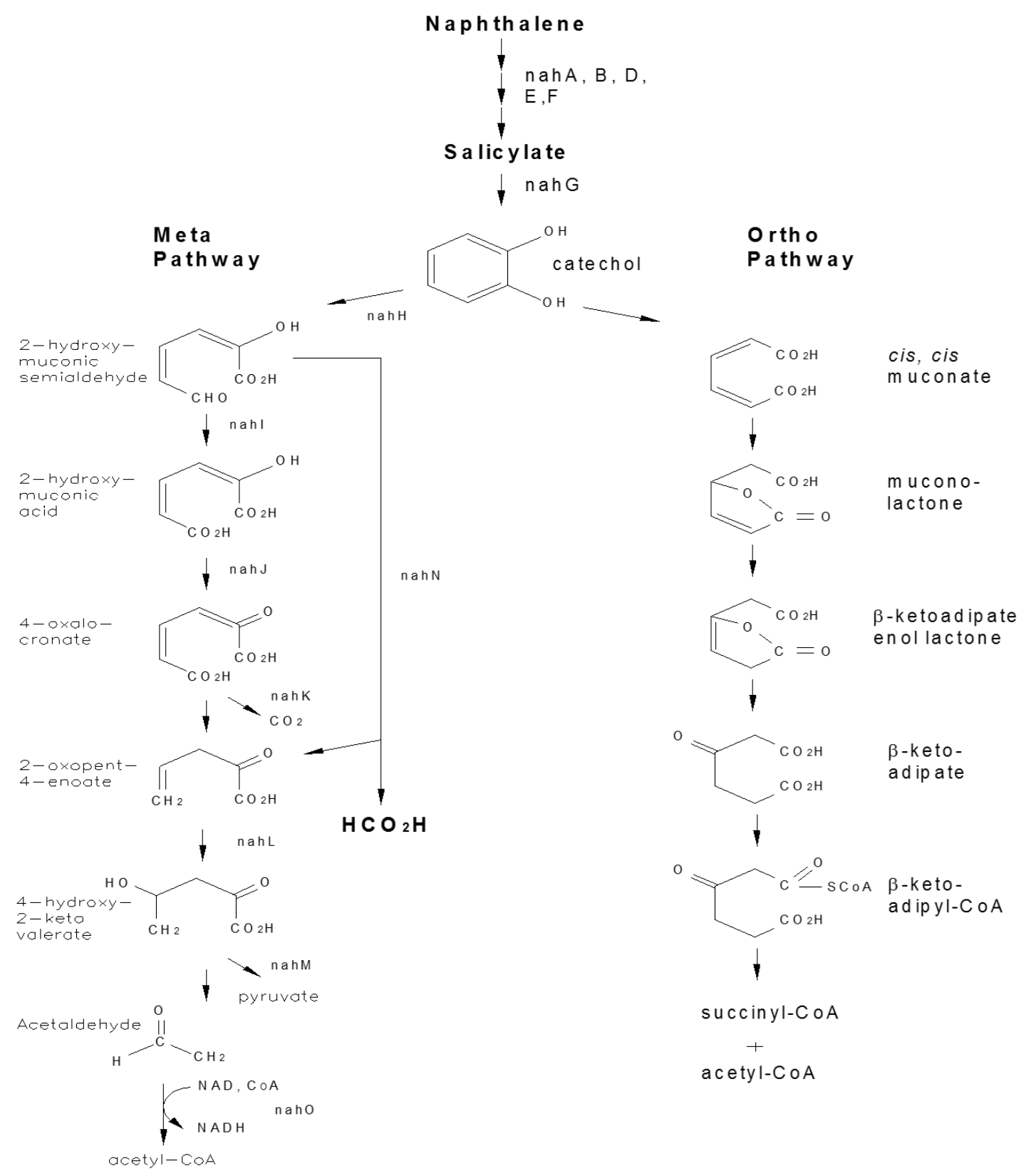

Fig. 6: Naphthalene degradation pathways, the nah gene specify the degradation of naphthalene to pyruvate and acetyl-CoA.

with nah gene belong to Pseudomonas genera with $99 \%$ homology which was specify for napthalene degradation to be pyruvate and acetyl-coenzyme-A (CoA) via meta cleavage.

\section{ACKNOWLEDGEMENT}

Thank you to Prof. Masafumi Yohda, Life and Bioscience Laboratory, Tokyo
University of Agriculture and Technology (TUAT), Tokyo, Japan.

\section{REFERENCES}

1. Abd-Elsalam, H., Hafed, E., Hussain, A.A., (2009), Isolation and Identification of Tree-Rings Polyaromatic Hydrocarbon (Anthracenes and Phenantrene) Degrading Bacteria, 
American-Eurasian Journal of

Agriculture \& Environment Sciences, 5(1), pp. 31-38.

2. Arun, K., Ashok, M., Rajesh, S., (2001), Crude Oil PAH Constitution, Degradation Pathway and Assiciated Bioremediation Microflora: an Overview, International Journal of Environmental Sciences, 1(7), pp. 14201439.

3. Das, K., Mukherjee, A.K., (2006), Differential Utilization of Pyrene as the Sole source of Carbon by Bacillus subtilis and Pseudomonas aeruginosa strain: Role of Biosurfactants in enhancing Bioavailability, Journal of Applied Microbiology, 102, pp. 195202.

4. Grimm, A.C., Harwood, C.S., (1997), Chemotaxis of Pseudomonas spp. to the Polyaromatic Hydrocarbon Napthalene, Applied and Environmental Microbiology, 63(10), pp. 4111-4115.

5. Guo, C., Dang, Z., Wong, Y., Tam, N.F., (2010), Biodegradation Ability and Dioxygenase gene of PAH-degrading Spingomonas and Mycobacterium strains Isolated from Mangrove Sediment, International Biodeterioration \& Biodegradation, 64, pp. 419-426.

6. Helmy, Q., Kardena, E., Nurachman, Z., Wisjnuprapto, (2010), Application of Biosurfactant Produced by Azotobacter vinelandii AV01 for Enhanced Oil Recovery and Biodegradation of Oil Sludge, International Journal of Civil \& Environmental Engineering, 10(1), pp. 7-14.

7. Herrick, J. B., E. L. Madsen, C. A. Batt, and W. C. Ghiorse., (1993), Polymer-ase chain reaction amplification of naphthalene catabolic and 16S rRNA gene sequences from indigenous sediment bacteria, Applied Environmental Microbiology, 59, pp. 687-694.

8. Iwabuchi, T., Harayama, S., (1997), Biochemical and Genetic Characterization of 2Carboxybenzaldehyde Dehydrogenase, an Enzyme Involved in Phenanthrene Degradation by Nocardioides sp. Strain KP7, Journal of Bacteriology, 179(20), pp. 6488-6495.

9. Kim, S-J., Kweon, O., Jones, R.C., Freeman, J.P., Edmondson, R.D., Cerniglia, C.E., (2007), Complete and Integrated pyrene degradation pathways in Mycobacterium vanbaalenii PYR-1 based on Systems Biology, Journal of Bacteriology, 189(2), pp. 464472.

10. Liu, W., Luo, Y., Teng, Y., (2010), Bioremediation of Oily Sludgecontaminated Soil by Stimulating Indigenous Microbes, Environmental Geochemical Health, 32, pp. 23-29.

11. Liang, Y., Gardner, D.R., Miller, C.D., Chen, D., Anderson, A.J., Weimer, B.C., Sims, R.C., (2006), Study of Biochemical Pathways and Enzymes Involved in Pyrene Degradation by Mycobacterium sp. Strain KMS, Applied and Environmental Microbiology, 72(12), pp. 7821-7828.

12. Prágai Z., Tjalsma H., Bolhuis A., van Dijl J. M., Venema G., Bron S., (1997), The signal peptidase II (Isp) gene of Bacillus subtilis. Microbiology 143:1327-1333.

13. Prágai Z., Harwood C. R., (2000), Screening mutants affected in their 
42 The Initial Dioxigenase Gene Squences Analysis of Marine Bacteria Strain M128

response to phosphate. in Functional analysis of bacterial genes: a practical manual. eds Schumann W., Ehrlich S. D., Ogasawara N. (John Wiley \& Sons, Ltd. Chichester, United Kingdom), pp 245249.

14. Okoh, A., Trejo-Hernandez, M. R., (2006), Remediation of petroleum hydrocarbon polluted systems: Exploiting the bioremediation strategies, African Journal of Biotechnology, 5(25), pp. 2520-2525.

15. Stingley, R.L., Khan, A.A., Cerniglia, C.E., (2004), Molecular Characterization of a Phenanthrene degradation pathway in
Mycobacterium vanbaalenii PYR1,Biochemical and Biophysical Research Communications, 322, pp. 133-146.

16. Seo, J-S., Keum, Y-S., Li, Q.X., (2009), Bacterial Degradation of Aromatic Compounds, International Journal of Environmental Resources and Public Health, 6, pp. 278- 309.

17. Zhou, H.W., Guo, C.L., Wong, Y.S., Tam, N.F.Y., (2006), Genetic diversity of dioxygenase gene in polycyclic aromatics hydrocarbons-degrading bacteria isolated from mangrove Sediment, FEMS Microbiology Letters, 262, pp. $148-157$. 